\title{
Ethnomedicinal value of shrub flora of Dachigam National Park traditionally used for health care practices by the inhabitants of Kashmir
}

\begin{abstract}
Aijaz Itoo, Junaid Malik, P.N. Shrivastava and K. AshoK
ABSTRACT

Primitive human societies have always relied on plants and plant products for various remedies. In certain areas, these folk medical prescriptions are endemic and have survived through ages from one generation to the next through word of mouth. They do not exist as written knowledge. The present study was undertaken with an objective of documenting the ethnobotanical information of medicinal plants of Dachigam National Park taking the help of local herbalists, elderly and knowledgeable people. A total of 26 medicinal shrub species belonging to 19 genera and 16 families were recorded in the study area.
\end{abstract}

Key words : Western Himalayas, Dachigam National Park, Shrubs, Ethnomedicinal value

How to cite this paper : Itoo, Aijaz, Malik, Junaid, Shrivastava, P.N. and Ashok, K. (2016). Ethnomedicinal value of shrub flora of Dachigam National Park traditionally used for health care practices by the inhabitants of Kashmir. Ann. Pharm. \& Pharm. Sci., 7 (1) : 5-13.

Article chronicle : Received : 10.02.2015; Revised : 04.03.2016; Accepted : 18.03.2016

\footnotetext{
Address for correspondence :

AIJAZ ITOO, Pest Control and Ayurvedic Drug Research Lab., S.S.L Jain P.G. College, VIDISHA (M.P.) INDIA

Email:aijaz_itoo@yahoo.com

Coopted auhors :

JUNAID MALIK, P.N. SHRIVASTAVA AND K. ASHOK, Pest Control and Ayurvedic Drug Research Lab., S.S.L Jain P.G. College, VIDISHA (M.P.) INDIA
} 